\title{
Effect of Potassium and Zinc on Growth and Yield of Baby Corn (Zea mays L.)
}

\author{
Ammisetty Sai Sravan*, Dhanush Reddy, Pavan Ganesh and Joy Dawson
}

Department of Agronomy, Sam Higginbottom University of Agriculture, Technology and Sciences, Prayagraj-211007, Uttar Pradesh, India

*Corresponding author

\section{A B S T R A C T}

Keywords

Babycorn, Zaid, Potassium, Zinc, growth, Yield attributes, Economics

\section{Article Info}

Accepted: 12 December 2020 Available Online: 10 January 2021
A field Experiment was conducted during Zaid 2020 at crop research farm, Department of agronomy, SHUATS, Prayagraj (U.P.). The experiment was laid out in Randomized Block Design, comprising of two factors and 9 treatments, each replicated thriceof 2 levels of Potassium viz. $\mathrm{K}_{1}(40 \mathrm{~kg}$ $\left.\mathrm{K}_{2} \mathrm{O} / \mathrm{ha}\right), \mathrm{K}_{2}\left(50 \mathrm{~kg} \mathrm{~K} \mathrm{~K}_{2} \mathrm{O} / \mathrm{ha}\right.$ )and 2 levels of Zinc viz.10 and $15 \mathrm{~kg} / \mathrm{ha}$ as basal. There were 9 treatments each being replicated thrice and laid out in Randomized Block Design. The results revealed that treatment T9 $(50 \mathrm{~kg}$ potassium $+15 \mathrm{~kg}$ zinc) recorded maximum Dry weight, Number of cobs per plant, cob length, cob girth, cob weight without husk, cob yield without husk, Green fodder and B: C ratio.

\section{Introduction}

Maize is popularly called as "Queen of cereals" as well as "miracle crop" because it has a greater yield potential. Maize is third most important cereal crop, next to rice and wheat. The novelty of maize is cultivating it predominantly for vegetable purpose as "baby corn". Baby corn is typically a maize ear (Zea mays L.) produced from regular corn plants which are harvested earlier, particularly when the silks have the size of 1-3 cm (Thavaprakash et al., 2005). Baby corn, a novel utilization of maize, is used a vegetable in many Asian countries. It is used as an ingredient in the preparation of many food items. It refers to whole, entirely edible corn of immature cob harvested just before fertilization at the silk emergence stage (Galinat, 1985). It is dehusked young ear of the female inflorence of maize plant, harvested at silk emergence before fertilization (Kapoor, 2002). Potassium activates many enzymes and plays an important role in the maintains of potential gradients across cell membranes and the generation of turgor pressure in plants. It regulate photosynthesis, protein synthesis and 
starch synthesis (Mengel and Kirkby, 1996). About $50 \%$ of Indian soils are deficient in zinc causing low level of zinc and yield losses in fodder crops and affecting the health of the livestock (Singh, 2011) and crop like maize has been found to respond to zinc application. Currently millions of hectare of crop plants are affected by zinc deficiency and approximately one third of the human population suffer from an inadequate intake of zinc. Low zinc content in grains and straw results in poor zinc nutrition of human beings and animals, which has received considerable attention (Cakmak, 2008). Zinc is important for the normal healthy growth of higher plants, animals and humans. Unavailability of critical zinc concentrations results in physiology stress as a results of irregular function of several enzyme systems and other metabolites. Among the field crops, maize occupies the third rank in demand for zinc next to rice and wheat, respectively (Meena et al., 2013).

\section{Materials and Methods}

The field experiment was conducted during Zaid 2020 at CRF (Crop Research Farm), Department of Agronomy, SHUATS, Prayagraj (UP). The soil of experimental plot was sandy loam in texture, nearly neutral in soil reaction $(\mathrm{pH} 7.3)$, low in organic carbon $(0.57 \%)$, available $\mathrm{N}(230 \mathrm{~kg} / \mathrm{ha})$, available $\mathrm{P}$ $(32.10 \mathrm{~kg} / \mathrm{ha})$ and available K $(346 \mathrm{~kg} / \mathrm{ha})$. The Treatments consists of 2 levels of Potassium viz. $\mathrm{K}_{1}(40 \mathrm{~kg} \mathrm{~K} 2 \mathrm{O} / \mathrm{ha}), \mathrm{K}_{2}(50 \mathrm{~kg} \mathrm{~K} 2 \mathrm{O} / \mathrm{ha})$ and 2 levels of zinc viz. $\mathrm{Zn}_{1}\left(10 \mathrm{~kg} \mathrm{ZnSO}_{4} / \mathrm{ha}\right)$, $\mathrm{Zn}_{2}\left(15 \mathrm{~kg} \quad \mathrm{ZnSO}_{4} / \mathrm{ha}\right)$, as both basal application, viz: whose effect is observed on Baby corn (var. G5417). There were 9 treatments each replicated thrice. The experiment was laid out in Randomized Block Design. The crop was sown on $17^{\text {th }}$ March 2020 using variety G5417 with a seed rate of $20 \mathrm{~kg} / \mathrm{ha}$. The recommended dose of $120 \mathrm{~kg}$ $\mathrm{N}, 60 \mathrm{~kg} \mathrm{P}, 40 \mathrm{~kg} \mathrm{~K}{ }_{2} \mathrm{O} \& 10 \mathrm{~kg} \mathrm{Zn}$ per ha was applied.

\section{Results and Discussion}

\section{Growth attributes}

The growth parameters like Plant height, Number of leaves, Dry weight were significantly affected by the application of different levels and potassium and zinc.

\section{Plant height (cm)}

Highest plant height $(184.41 \mathrm{~cm})$ was recorded with application of Potassium $50 \mathrm{~kg} / \mathrm{ha}+$ zinc $15 \mathrm{~kg} / \mathrm{ha}$ which was significantly superior over rest of the treatments and remained on par with application $40 \mathrm{~kg} / \mathrm{ha}+$ zinc $10 \mathrm{~kg} / \mathrm{ha}(176.41$ $\mathrm{cm})$, potassium $40 \mathrm{~kg} / \mathrm{ha}+$ zinc 15 $\mathrm{kg} / \mathrm{ha}(178.39 \mathrm{~cm})$, potassium $50 \mathrm{~kg} / \mathrm{ha}+$ zinc $10 \mathrm{~kg} / \mathrm{ha}(179.40 \mathrm{~cm})$. The plant height was significantly influenced due to the application of potassium significantly higher plant height was observed with application of Potassium $50 \mathrm{~kg} / \mathrm{ha}+$ zinc $15 \mathrm{~kg} / \mathrm{ha}$ as compared to control. The higher plant height with potassium application might affect cell metabolism, enzymes activity, regulate cell osmosis and increased absorption of water and photosynthesis which promote the more plant growth (Yadav et al., 2014) and (Maleki et al., 2014). Addition of $\mathrm{Zn}$ significantly increases the plant height at 30 DAS and harvest of plant. Significantly higher plant height was observed with the application of Potassium $50 \mathrm{~kg} / \mathrm{ha}+$ zinc $15 \mathrm{~kg} / \mathrm{ha}$. Its might be due to zinc plays a role in metabolic activity and physiological reaction and act as a catalyzing enzymes transformation of carbohydrates, chlorophyll and protein synthesis (Srinivasan, 1992).

\section{Number of leaves per plant}

In the present investigation, highest number of leaves (11.67) was recorded with application of Potassium $50 \mathrm{~kg} / \mathrm{ha}+$ zinc $15 \mathrm{~kg} / \mathrm{ha}$ which was significantly superior over 
rest of the treatments and remained on par with application potassium $40 \mathrm{~kg} / \mathrm{ha}+$ zinc 15 $\mathrm{kg} / \mathrm{ha}(11.33)$, potassium $50 \mathrm{~kg} / \mathrm{ha}+$ zinc 10 $\mathrm{kg} / \mathrm{ha}(11.40)$. Interaction between soil moisture levels and potassium had a significant effect on leaf number. Potassium nutrition increases number of leaves. $\mathrm{Zn}$ is an important element in crops, because it is necessary for synthesize chlorophyll (kubaret al., 2013).

\section{Dry weight (g) per plant}

Data presented in (Table no-1)revealed that maximum plant dry weight (88.73) was recorded in $\mathrm{T}_{9}(50 \mathrm{~kg}$ potassium $+15 \mathrm{~kg}$ zinc), which was significantly superior over rest of the treatments. And on par with $\mathrm{T}_{8}$ $\left(50 \mathrm{~kg}\right.$ potassium $+10 \mathrm{~kg}$ zinc) $(86.81), \mathrm{T}_{6}(40$ $\mathrm{kg}$ potassium $+15 \mathrm{~kg}$ zinc) $(84.33), \mathrm{T}_{5}(40 \mathrm{~kg}$ potassium $+10 \mathrm{~kg}$ zinc) (83.61). Application of Potassium increased dry weight as the content of chlorophyll increases which leads to accumulation of starch. The interaction effect between potassium and Zinc was found significant in respect of green and dry matter yield. Potassium associated with the movement of water, nutrients and carbohydrates in plant tissue these results similar to Shrama et al., (2018).

\section{Yield and yield attributes}

Yield attributes and yield were also significantly affected by the application of different levels and potassium and zinc.

\section{Number of cobs per plant}

Data presented in Table 2 revealed that maximum number of Cobs per plant (2.40) was recorded in $\mathrm{T}_{9}(50 \mathrm{~kg}$ potassium $+15 \mathrm{~kg}$ zinc), which was significantly superior over rest of the treatments except. And on par with $_{8}(50 \mathrm{~kg}$ potassium $+10 \mathrm{~kg}$ zinc) $(2.27)$, $\mathrm{T}_{6}(40 \mathrm{~kg}$ potassium $+15 \mathrm{~kg}$ zinc) $(2.20)$ and $\mathrm{T}_{5}(40 \mathrm{~kg}$ potassium $+10 \mathrm{~kg}$ zinc) $(2.15)$.
Increase in cobs per plant by potassium application was probably due to its influence on various enzymatic activities. which similar results in Aravinth et al., (2011)

\section{Length of cobs}

Table 2 revealed that maximum length of Length of cob $(\mathrm{cm})$, maximum $(19.36 \mathrm{~cm})$ was obtained with application of Potassium $50 \mathrm{~kg} / \mathrm{ha}+$ zinc $15 \mathrm{~kg} / \mathrm{ha}$ which was significantly superior over rest of all the treatments except with application potassium $50 \mathrm{~kg} / \mathrm{ha}+$ zinc $10 \mathrm{~kg} / \mathrm{ha}(19.20 \mathrm{~cm})$ and other treatments were at par. Increase in cob length with potash fertilization might be due an role of potassium in increasing cell division, improved plant growth conditions in water use efficiency and also results in quick transportation towards grain.

The continuous filling of grains due to sufficient photosynthesis might have resulted in increased length and size of the cob. Which similar results were found in Kalpana and Krishnarjun (2007).

\section{Girth of cobs}

Data presented in Table 2 revealed that maximum girth of cob per plant $(8.02 \mathrm{~cm})$ was recorded in $\mathrm{T}_{9}(50 \mathrm{~kg}$ potassium $+15 \mathrm{~kg}$ zinc) which statistically on par with $\mathrm{T}_{8}(50 \mathrm{~kg}$ potassium $+10 \mathrm{~kg}$ zinc) $(7.61), \mathrm{T}_{6}(40 \mathrm{~kg}$ potassium $+15 \mathrm{~kg}$ zinc) $(7.44 \mathrm{~cm})$. Increase in Cob girth due to the role of potassium in increasing cell division, improved plant growth conditions in water use efficiency and also results in quick transportation towards grain. This may be due to continuous filling of grains with sufficient photosynthates that lead to increased size of cob and it resulted in increased cob girth. $=$ which similar results were found in kalpana and krishnarjuna (2007). 
Table.1 Effect of potassium and zinc growth and yield of Babycorn

\begin{tabular}{|c|c|c|c|}
\hline Treatment & Plant height (cm) & Number of leaves/ plant & Dry weight $(g)$ \\
\hline $\mathrm{T}_{1}$. Potassium $0 \mathrm{~kg} / \mathrm{ha}+$ zinc $0 \mathrm{~kg} / \mathrm{ha}$ & 160.68 & 9.73 & 74.33 \\
\hline $\mathrm{T}_{2}$. Potassium $0 \mathrm{~kg} / \mathrm{ha}+$ zinc $10 \mathrm{~kg} / \mathrm{ha}$ & 162.94 & 10.07 & 76.21 \\
\hline $\mathrm{T}_{3}$. Potassium $0 \mathrm{~kg} / \mathrm{ha}+$ zinc $15 \mathrm{~kg} / \mathrm{ha}$ & 163.37 & 10.20 & 77.66 \\
\hline $\mathrm{T}_{4}$. Potassium $40 \mathrm{~kg} / \mathrm{ha}+$ zinc $0 \mathrm{~kg} / \mathrm{ha}$ & 165.51 & 10.47 & 79.62 \\
\hline $\mathrm{T}_{5}$. Potassium $40 \mathrm{~kg} / \mathrm{ha}+$ zinc $10 \mathrm{~kg} / \mathrm{ha}$ & 176.41 & 10.80 & 83.61 \\
\hline $\mathrm{T}_{6}$. Potassium $40 \mathrm{~kg} / \mathrm{ha}+$ zinc $15 \mathrm{~kg} / \mathrm{ha}$ & 178.39 & 11.33 & 84.33 \\
\hline $\mathrm{T}_{7 .}$ Potassium $50 \mathrm{~kg} / \mathrm{ha}+$ zinc $0 \mathrm{~kg} / \mathrm{ha}$ & 169.32 & 10.53 & 81.50 \\
\hline $\mathrm{T}_{8}$. Potassium $50 \mathrm{~kg} / \mathrm{ha}+$ zinc $10 \mathrm{~kg} / \mathrm{ha}$ & 179.40 & 11.40 & 86.81 \\
\hline $\mathrm{T}_{9 .}$ Potassium $50 \mathrm{~kg} / \mathrm{ha}+$ zinc $15 \mathrm{~kg} / \mathrm{ha}$ & 184.41 & 11.67 & 88.73 \\
\hline $\mathrm{F}-$ test & $\mathrm{S}$ & $\mathrm{S}$ & $\mathrm{S}$ \\
\hline $\operatorname{SEm}( \pm)$ & 3.51 & 0.19 & 2.03 \\
\hline $\mathrm{CD}(5 \%)$ & 10.53 & 0.58 & 6.10 \\
\hline
\end{tabular}

Table.2 Yield attributes of Effect of potassium and zinc growth and yield of Babycorn

\begin{tabular}{|c|c|c|c|c|c|}
\hline Treatments & $\begin{array}{c}\text { No. of cobs/ } \\
\text { plant }\end{array}$ & $\begin{array}{l}\text { Cob length } \\
\text { (cm) }\end{array}$ & $\begin{array}{l}\text { Cob girth } \\
\text { (cm) }\end{array}$ & $\begin{array}{l}\text { Cob weight with } \\
\text { husk (gm) }\end{array}$ & $\begin{array}{c}\text { Cob weight } \\
\text { without husk (gm) }\end{array}$ \\
\hline $\mathrm{T}_{1}$. Potassium $0 \mathrm{~kg} / \mathrm{ha}+$ zinc $0 \mathrm{~kg} / \mathrm{ha}$ & 1.53 & 15.57 & 5.50 & 35.58 & 9.89 \\
\hline $\mathrm{T}_{2}$. Potassium $0 \mathrm{~kg} / \mathrm{ha}+$ zinc $10 \mathrm{~kg} / \mathrm{ha}$ & 1.60 & 15.83 & 5.58 & 36.17 & 10.09 \\
\hline $\mathrm{T}_{3 .}$ Potassium $0 \mathrm{~kg} / \mathrm{ha}+$ zinc $15 \mathrm{~kg} / \mathrm{ha}$ & 1.80 & 16.79 & 5.69 & 37.92 & 10.21 \\
\hline $\mathrm{T}_{4}$. Potassium $40 \mathrm{~kg} / \mathrm{ha}+$ zinc $0 \mathrm{~kg} / \mathrm{ha}$ & 2.00 & 17.15 & 6.04 & 39.79 & 10.25 \\
\hline $\mathrm{T}_{5}$. Potassium $40 \mathrm{~kg} / \mathrm{ha}+$ zinc $10 \mathrm{~kg} / \mathrm{ha}$ & 2.15 & 17.79 & 6.92 & 43.35 & 10.77 \\
\hline $\mathrm{T}_{6}$. Potassium $40 \mathrm{~kg} / \mathrm{ha}+$ zinc $15 \mathrm{~kg} / \mathrm{ha}$ & 2.20 & 18.44 & 7.44 & 43.46 & 10.96 \\
\hline $\mathrm{T}_{7 .}$ Potassium $50 \mathrm{~kg} / \mathrm{ha}+$ zinc $0 \mathrm{~kg} / \mathrm{ha}$ & 2.07 & 17.18 & 6.15 & 41.21 & 10.50 \\
\hline $\mathrm{T}_{8}$. Potassium $50 \mathrm{~kg} / \mathrm{ha}+$ zinc $10 \mathrm{~kg} / \mathrm{ha}$ & 2.27 & 19.20 & 7.61 & 45.69 & 11.27 \\
\hline $\mathrm{T}_{9}$. Potassium $50 \mathrm{~kg} / \mathrm{ha}+$ zinc $15 \mathrm{~kg} / \mathrm{ha}$ & 2.40 & 19.36 & 8.02 & 46.16 & 11.56 \\
\hline F- test & $\mathrm{S}$ & $\mathrm{S}$ & $\mathrm{S}$ & $\mathrm{S}$ & $\mathrm{S}$ \\
\hline $\operatorname{SEm}( \pm)$ & 0.09 & 0.68 & 0.20 & 1.00 & 0.15 \\
\hline $\mathrm{CD}(5 \%)$ & 0.26 & 2.05 & 0.59 & 3.01 & 0.45 \\
\hline
\end{tabular}


Table.3 Yield of Effect of potassium and zinc growth and yield of Babycorn

\begin{tabular}{|c|c|c|c|}
\hline Treatments & Cob yield with husk (t/ha) & Cob yield without husk (t/ha) & Green fodder (t/ha) \\
\hline $\mathrm{T}_{1}$. Potassium $0 \mathrm{~kg} / \mathrm{ha}+$ zinc $0 \mathrm{~kg} / \mathrm{ha}$ & 6.42 & 1.82 & 28.51 \\
\hline $\mathrm{T}_{2}$. Potassium $0 \mathrm{~kg} / \mathrm{ha}+$ zinc $10 \mathrm{~kg} / \mathrm{ha}$ & 6.80 & 2.15 & 29.45 \\
\hline $\mathrm{T}_{3}$. Potassium $0 \mathrm{~kg} / \mathrm{ha}+$ zinc $15 \mathrm{~kg} / \mathrm{ha}$ & 7.41 & 2.31 & 29.98 \\
\hline $\mathrm{T}_{4 .}$ Potassium $40 \mathrm{~kg} / \mathrm{ha}+$ zinc $0 \mathrm{~kg} / \mathrm{ha}$ & 7.94 & 2.43 & 30.75 \\
\hline $\mathrm{T}_{5}$. Potassium $40 \mathrm{~kg} / \mathrm{ha}+$ zinc $10 \mathrm{~kg} / \mathrm{ha}$ & 8.62 & 2.87 & 32.96 \\
\hline $\mathrm{T}_{6} . \quad$ Potassium $40 \mathrm{~kg} / \mathrm{ha}+$ zinc $15 \mathrm{~kg} / \mathrm{ha}$ & 9.27 & 3.26 & 33.34 \\
\hline $\mathrm{T}_{7}$. Potassium $50 \mathrm{~kg} / \mathrm{ha}+$ zinc $0 \mathrm{~kg} / \mathrm{ha}$ & 8.30 & 2.52 & 32.33 \\
\hline $\mathrm{T}_{8} . \quad$ Potassium $50 \mathrm{~kg} / \mathrm{ha}+$ zinc $10 \mathrm{~kg} / \mathrm{ha}$ & 9.45 & 3.41 & 35.12 \\
\hline $\mathrm{T}_{9 .}$ Potassium $50 \mathrm{~kg} / \mathrm{ha}+$ zinc $15 \mathrm{~kg} / \mathrm{ha}$ & 9.69 & 3.64 & 35.65 \\
\hline $\mathrm{F}$-test & $\mathrm{S}$ & $\mathrm{S}$ & $\mathrm{S}$ \\
\hline $\operatorname{SEm}( \pm)$ & 0.15 & 0.14 & 0.83 \\
\hline $\mathrm{CD}(5 \%)$ & 0.44 & 0.42 & 2.49 \\
\hline
\end{tabular}

Table.4 Economics of Effect of potassium and zinc growth and yield of Babycorn

\begin{tabular}{|l|c|c|c|}
\hline Treatment & $\begin{array}{c}\text { Gross return } \\
\text { (INR/ha) }\end{array}$ & $\begin{array}{c}\text { Net return } \\
\text { (INR/ha) }\end{array}$ & Benefit cost ratio \\
\hline $\mathrm{T}_{1}$. Potassium 0kg/ha + zinc 0kg/ha & 81900 & 49240 & 1.09 \\
\hline $\mathrm{T}_{2}$. Potassium 0kg/ha + zinc 10kg/ha & 96900 & 64240 & 1.42 \\
\hline $\mathrm{T}_{3}$. Potassium 0kg/ha + zinc $15 \mathrm{~kg} / \mathrm{ha}$ & 103800 & 71140 & 1.57 \\
\hline $\mathrm{T}_{4}$. Potassium 40kg/ha + zinc 0kg/ha & 109500 & 76200 & 1.66 \\
\hline $\mathrm{T}_{5}$. Potassium 40kg/ha + zinc 10kg/ha & 129000 & 95700 & 2.08 \\
\hline $\mathrm{T}_{6}$. Potassium 40kg/ha + zinc 15kg/ha & 146700 & 113400 & 2.47 \\
\hline $\mathrm{T}_{7}$. Potassium 50kg/ha + zinc 0kg/ha & 113400 & 79940 & 1.73 \\
\hline $\mathrm{T}_{8}$. Potassium 50kg/ha + zinc 10kg/ha & 153600 & 120140 & 2.60 \\
\hline $\mathrm{T}_{9}$. Potassium 50kg/ha + zinc 15kg/ha & 163800 & 130340 & 2.83 \\
\hline
\end{tabular}




\section{Weight of cobs}

That presented (Table 2) revealed that highest Weight of husked baby corn, maximum $(46.16 \mathrm{~g})$ was obtained with application of potassium $50 \mathrm{~kg} / \mathrm{ha}+$ zinc $15 \mathrm{~kg} / \mathrm{ha}$ which was significantly superior over rest of all the treatments with application potassium $50 \mathrm{~kg} / \mathrm{ha}+$ zinc $10 \mathrm{~kg} / \mathrm{ha}(45.69 \mathrm{~g})$ were at par. As per the metabolites and nutrients to develop reproductive structure seems to have resulted in increased cob girth, cob length, number of cobs, number of grains per cob, grain rows per cob, cob weight with and without husk, 100 grain weight and seed weight. Which similar results were found in Sahoo and Mahapatra (2007).

That presented revealed that Weight of dehusked baby corn, maximum (11.56 g) was obtained with application potassium $50 \mathrm{~kg} / \mathrm{ha}$ + zinc $15 \mathrm{~kg} / \mathrm{ha}$ and minimum potassium 0 $\mathrm{kg} / \mathrm{ha}+$ zinc $0 \mathrm{~kg} / \mathrm{ha}$ was with control $(9.89$ g). There was no significant difference between different treatment combinations. The application of Potassium 50kg/ha + zinc $15 \mathrm{~kg} / \mathrm{ha}$ is higher and minimum in with application of Potassium 0kg/ha + zinc 0kg/ha and at par values with application of Potassium 50kg/ha + zinc 10kg/h (11.27) conducted a field experiment and observed that number of cobs ha1, cobs/plant, cob weight, grains/cob, kernel weight, green cob yield, green fodder yield and fresh kernel yield of sweet corn were significantly higher under 120:26.5:50 N, P2O5 and $\mathrm{K} 2 \mathrm{O} \mathrm{kg}$ ha/1 than control. which similar results were found in sahoo and mahapatra (2007).

\section{Yield of cobs}

Cob yield of husked baby corn ( $\mathrm{kg} / \mathrm{ha})$, maximum (9.69 t/ha) was obtained with application of potassium $50 \mathrm{~kg} / \mathrm{ha}+$ zinc $15 \mathrm{~kg} / \mathrm{ha}$ which was significantly superior over rest of all the treatments except with application potassium $50 \mathrm{~kg} / \mathrm{ha}+$ zinc $10 \mathrm{~kg} / \mathrm{ha}$ $(9.45 \mathrm{t} / \mathrm{ha})$ and other treatments were at par. found that each successive level of zinc application correspondingly improved the yield of cob and corn up to the highest level and application of 5 and $10 \mathrm{~kg} \mathrm{Zn} \mathrm{ha}$ ${ }^{1}$ increased cob yield. Which similar results were found in Kumar et al., (2015).

Data presented in Table 3 Cob yield of dehusked baby corn $(\mathrm{kg} / \mathrm{ha})$, maximum (3.64 $\mathrm{t} / \mathrm{ha}$ ) was obtained with application of potassium $50 \mathrm{~kg} / \mathrm{ha}+$ zinc $15 \mathrm{~kg} / \mathrm{ha}$ which was significantly superior over rest of all the treatments except with application potassium $50 \mathrm{~kg} / \mathrm{ha}+$ zinc $10 \mathrm{~kg} / \mathrm{ha}$ (3.41 t/ha). reported that among the treatments which received zinc through different methods of zinc application, the treatment which received zinc through soil application as zinc sulphate at the rate of $10 \mathrm{~kg} \mathrm{ha}^{-1}$ was found to be superior in increasing the grain yield effective method of zinc application. Which similar results were found in Aryas and Singh (2000), Dwivedi et al., (2002).

\section{Green fodder yield}

The experiment revealed that highest Fodder yield of dehusked baby corn ( $\mathrm{kg} / \mathrm{ha})$, maximum (35.65 t/ha) was obtained with application of potassium $50 \mathrm{~kg} / \mathrm{ha}+$ zinc $15 \mathrm{~kg} / \mathrm{ha}$ which was significantly superior over rest of all the treatments except with application potassium $50 \mathrm{~kg} / \mathrm{ha}+$ zinc $10 \mathrm{~kg} / \mathrm{ha}$ (35.12 t/ha). Potassium application is the reason for the increase in green fodder yield due to higher plant height and dry matter production per plant. carried out a field experiment and showed that application of 150:75:40 kg NPK ha ${ }^{1}$ resulted in significant improvement in 12 husked, dehusked and green fodder yields compared to 100:50:27 $\mathrm{kg}$ NPK ha ${ }^{1}$ treatment in baby corn. Which similar results found in Rajanna et al., (2006). 


\section{Economics}

Data presented in Table 3 revealed that highest gross returns (Rs 163800) Net returns (Rs 130340) and maximum benefit cost ratio Application of Potassium 50kg/ha + zinc $15 \mathrm{~kg} / \mathrm{ha}$ (T9) recorded higher Benefit cost ratio (2.83) as against other treatments which was closely followed by application of Potassium 50kg/ha + zinc $10 \mathrm{~kg} / \mathrm{ha}(\mathrm{T} 8)$, Potassium 40kg/ha + zinc $15 \mathrm{~kg} / \mathrm{ha}(\mathrm{T} 6)$ and application of Potassium 40kg/ha + zinc $10 \mathrm{~kg} / \mathrm{ha}$ (T5). Similar results are found with Kumar and Kubsad et al., (2017).

\section{Acknowledgement}

I express gratitude to my advisor Prof. (Dr.) Joy Dawson for constant support and guideline. I am indebted to Prof. (Dr.) Thomas Abraham and Dr. Vikram Singh and all the faculty members of SHUATS for inspiration.

\section{References}

Aravinth, V., Kuppuswamy, G. and Ganapathy, M. (2011). Growth and yield of baby corn (Zea mays L..) as influenced by intercropping, planting geometry and nutrient management. Indian Journal of Agricultural Sciences., 81(9): 875-877.

Arya KC, Singh SN. Effect of different levels of phosphorus and zinc on yield and nutrients uptake of maize (Zea mays L..) with and without irrigation. Indian journal of Agronomy. 2000; 45(4):717-
721.

Dwivedi, S.K., Singh, R.S. and Diwivedi, K.N. (2002). Effect of Sulphur and zinc nutrition on yield and quality of maize in typicustochrept soil of Kanpur. Journal India of Soil Science., 50(1):7074.

Kalpana, R. and Krishnarajan, J. 2002.Effect of dose and time of potassium application on yield and quality of baby corn. Agriculture Sciences Digest.22: 5960.

Kumar, R., Bohra, J.S., Kumawat, N. and Singh, A.K. 2015. Fodder yield, nutrient uptake and quality of baby corn (Zea mays $L$. .) as influenced by NPKS and $\mathrm{Zn} \mathrm{fertilization.} \mathrm{Research} \mathrm{crops.,}$ 16:243-24, DOI: $10.5958 / 2348$ 7542.2015.00036.4.

Mahapatra, A. K. Barik and G. C. Mishra. 2018. Integrated Nutrient Management on Baby Corn (Zea mays L..) International Journal of Bio-resource and Stress Management 2018, 9(1):044048.

Rajanna, A.E., Ramachandrappa, B.K., Nanjappa, H.V. and Soumya, T.M. 2006. Soil plant water status and yield of baby corn (Zea mays L.) as influenced by irrigation and fertility levels. Mysore Journal Agricultural Sciences., 40:74- 82.

Sahoo, S. C. and Panda, M. M. 1999. Effect of level of nitrogen and plant population on yield of baby corn (Zea mays L..). Indian Journal of Agricultural Sciences., 69 (2): 157-158.

\section{How to cite this article:}

Ammisetty Sai Sravan, Dhanush Reddy, Pavan Ganesh and Joy Dawson. 2021. Effect of Potassium and Zinc on Growth and Yield of Baby Corn (Zea mays L.). Int.J.Curr.Microbiol.App.Sci. 10(01): 1723-1729. doi: https://doi.org/10.20546/ijcmas.2021.1001.202 